\title{
DEFAMATION A DEUX: INCIDENTAL DEFAMATION AND THE SULLIVAN DOCTRINE
}

Constitutional guarantees of freedom of speech and press require that a public official seeking relief for defamatory statements relating to his official conduct demonstrate that the allegedly actionable statements were made with actual malice-with knowledge they were false or with reckless disregard of whether they were false or not. ${ }^{1}$ This requirement is a qualified or conditional ${ }^{2}$ privilege. $^{3}$

Reaction to Nerv York Times Co. v. Sullivan, both judicial and academic, has focused upon the probable interpretation of "public official." 4 As the volume of litigation increases, ${ }^{5}$ however, courts will inevitably be

1 New York Times Co. v. Sullivan, 376 U.S. 254, 279-80 (1964). Garrison v. Louisiana, 379 U.S. 64 (1964), imposed the same requirements upon the state in criminal libel prosecutions.

The Supreme Court defined neither "public official" nor "official conduct" reserving such questions for future consideration. New York Times v. Sullivan, sipra at $283 \mathrm{n} .23$. As to the probable definition of public official, see notes $4-5$ infra.

Defamation cases have frequently required courts to distinguish between statements relating to an official's public and private conduct. It is to these cases that courts will probably look for a definition of official conduct. See Boyer, Fair Comment, 15 OHro St. L.J. 280, 292-94 (1954); Hallen, Fair Comment, 8 TeXas L. Rev. $41,81-83$ (1929). The Court has indicated that official conduct should receive a broad interpretation, for "anything which might touch on an official's fitness for office is relevant." Garrison v. Louisiana, supra at 77.

2 RESTATENENT, TORTS $\$ \$ 593-612$ (1938) [hereinafter cited as RestatEMEENT] uses the latter term.

3 ProssER, TORTs § 110, at 815 (3d ed. 1964) [hereinafter cited as Prosser]. The Court's definition of actual malice is considerably less advantageous to plaintiffs than that usually required to prove abuse of a qualified privilege-that the defendant was motivated by any improper motive or purpose. See, e.g., I HARPER \& JaArES, TORTS $\$ 5.27$ (1956) [hereinafter cited as HARPER \& JAMES]. However, under either formulation of the test, once defendant shows that the statements were uttered in a privileged context, plaintiff has the burden of proving malice. PrOSSER $\$ 110$, at 823; RESTATEMENT $\$ 613(1)(\mathrm{g})$.

4 See, e.g., 113 U. PA. L. REv. 284 (1964); 51 VA. L. Rev. 106 (1965). One federal circuit court has already indicated that the term will eventually be extended to encompass any "participant in public debate on an issue of grave public concern . Pauling v, News Syndicate Co., 335 F.2d 659, 671 (2d Cir. 1964), cert. denied, 379 U.S. 968 (1965); see Nusbaum v. Newark Morning Ledger Co., 86 N.J. Super. 132, 153, 206 A.2d 185, 197 (App. Div. 1965). It is arguable that the Sullivan opinion will become a stepping stone to a rule of conditional privilege for all defamations connected with public men rather than public officials. A federal district court recently depended upon Sullivan in dismissing a newspaper libel complaint lodged by former General Edwin Walker regarding his unofficial involvement in segregationist activities. Walker v. Courier Journal and Louisville Times Co., 34 U.S.L. WEEK 2176 (U.S.D.C. Ky., Sept. 23, 1965). However, a Texas court affirmed a $\$ 500,000$ judgment in favor of General Walker without mention of Sullivan. Associated Press v. Walker, 393 S.W.2d 671 (Tex. Civ. App. 1965).

$5 \mathrm{~A}$ wide variety of individuals has already been included in the public official category: Henry v. Collins, 380 U.S. 356 (1965) (county attorney and police chief); Pearson v. Fairbanks Publishing Co., 33 U.S.L. WeEk 2307 (Alaska Super. Ct. Novi $25,1964)$ (nationally known newspaper columnist campaigning for candidate); Proesel v. Myers Publishing Co., 48 Ill. App. 2d 402, 199 N.E.2d 73 (1964) (president of Illinois village); Kennedy y. Mid-Continent Telecasting, Inc., 193 Kan. 544, 394 P.2d 400 (1964) (county commissioner); Matassa v. Bel, 246 La. 294, 164 So. 2d 332 (1964) (constable running for re-election); Baer v. Rosenblatt, 106 N.H. 26, 203 A.2d 773 (1964), cert. granted, 380 U.S. 941 (1965) (appointed director of public 
faced with a problem as yet unresolved: Does the qualified privilege to make defamatory remarks about a public official in his public capacity also immunize defamation of a private party incidental to that of a public official ? ${ }^{6}$ Thus suppose a newspaper editorial asserts that Congressman Crafty was bribed by Irving Injured to introduce a private bill. In a libel action, the congressman would have to prove actual malice as defined by Sullivan; is the same burden constitutionally imposed on Injured? 7

Since Sullivan, three state courts have confronted situations posing such a dilemma. ${ }^{8}$ In Gilberg $v$. Goffi, ${ }^{9}$ plaintiff, a law partner of the town mayor, alleged that he had been defamed by an aldermanic candidate's campaign speech charging that the mayor's firm was practicing law under conditions demonstrating a conflict of interest. After denying relief on the ground that the remarks lacked sufficient specificity to be "of and concerning" the plaintiff, the court stated alternatively: "While the plaintiff

recreation area); Fegley v. Morthimer, $204 \mathrm{~Pa}$. Super. 54, 202 A.2d 125 (1964) (member of school board and chairman of its planning committee). There have also been exclusions from the category: Faulk v. Aware, Inc., 14 N.Y.2d 954, 202 N.E.2d 372,253 N.Y.S.2d 990 (1964), cert. denied, 380 U.S. 916 (1965) (radio and television personality); Dempsey v. Time, Inc., 43 Misc. 2d 754, 252 N.Y.S.2d 186 (Sup. Ct. 1964) (nationally known sports figure); Harper v. National Review, Inc., 33 U.S.I. WEEK 2341 (N.Y. Sup. Ct. Dec. 22, 1964) (private individual involved in public debate). But see Pauling v. News Syndicate Co., supra note 4.

6 Traditionally, the extent of any privilege is a question for the court. The judge must determine whether the facts and circumstances, including the relationship of the parties, were such as to justify classifying defendant's statements as privileged. Once this classification is made, the jury determines such subsequent issues as whether plaintiff has shown the actual malice necessary to abuse a qualified privilege. This Comment is concerned with the former question. See generally PROSSER $\S 110$, at 823; REsTATEMENT \$ 619.

7 Prior to Sullivan an overwhelming majority of state courts had adopted what was termed the privilege of "fair comment," which did not extend to false statements of fact, being limited solely to opinion. 1 HARPER \& JAMES \$ 5.28, at 459; Prosser $\$ 110$, at 815 . See generally Noel, Defamation of Public Officers and Candidates, 49 Colum. L. REv. 875 (1949). Only ten states-Arizona, California, Connecticut, Iowa, Kansas, Minnesota, New Hampshire, North Carolina, South Dakota and West Virginia-had adopted the Sullivan privilege. Noel, sipra at 897 , lists nine states; Charles Parker Co. v. Silver City Crystal Co., 142 Conn. 605, 116 A.2d 440 (1955), indicates Connecticut's adoption. Under the fair comment rule the question of incidental defamation never seems to arise. All misstatements of fact were unprivileged. See Bell Publishing Co. v. Garrett Eng'r Co., 141 Tex. 51, 170 S.W.2d 197 (1943), where defendant, in a political advertisement opposing the construction of a municipal electric plant, asserted that plaintiff engineering firm was not qualified to prepare the plans. The court found that, since the statements were false, the privilege of fair comment was not applicable. Cf. Tilles v. Pulitzer Publishing Co., 241 Mo. 609, 145 S.W. 1143 (1912).

8 Although courts were rarely faced with incidental defamations in a political context before Sullivan, a Connecticut case arising out of a mayoralty campaign squarely posed the issue, see Charles Parker Co. v. Silver City Crystal Co., supra note 7 . In Parker, a candidate alleged during a campaign speech that because of the policies of the incumbent mayor, one of the town's chief industries was up for sale resulting in a loss of 1,000 jobs. The company sued alleging that the statement imputed a lack of managerial skill. The court found the incidental defamation privileged, employing a rationale almost identical to that later invoked in Sullivan: "Courts must be careful not to permit the law of libel and slander to encroach unwarrantably upon the field of free debate." Compare id. at 607, 116 A.2d at 445, with New York Times Co. v. Sullivan, 376 U.S. 254, 272 (1964). Sefton v. Baskin, 37 N.Z.L.R. 157 (1917), disposed of a similar problem by use of a relevancy test.

921 App. Div. 2d 517, 251 N.Y.S.2d 823 (1964), aff'd mem., 15 N.Y.2d 1023, 207 N.E.2d 620,260 N.Y.S.2d 29 (1965). 
claims that he was not a public official, it is our opinion . . . that plaintiff's action is so closely related to criticism of a public official that the Times case is determinative and that the plaintiff has no justiciable claim." 10 The court reasoned that it would be "anomalous" to permit the partner to recover without a showing of actual malice while precluding the mayor's action absent a similar showing. ${ }^{11}$ Block v. Benton, ${ }^{12}$ another New York case, presented a similar factual pattern: two of the plaintiffs were town assessors running for re-election; the other was a property owner. A campaign advertisement accused the assessors of incompetence, depicting the property owner's home as one of the many properties which had been improperly valued. ${ }^{13}$ While dismissing the complaint, the court assumed without further explanation that different standards should be applied to the claims of the public and private plaintiffs. ${ }^{14}$ In State $v$. Browne, ${ }^{15}$ a criminal libel prosecution, defendant, the incumbent mayor, circulated a campaign flier asserting that an affidavit issued by his opponent was false. The complainants were the opposing candidate, the affiant, a notary who had verified the affidavit and a secretary who had seen the original document upon which the affidavit was based. The court concluded that the indictment for libel of the candidate was insufficient when measured by Sullivan standards and that the indictment for libel of the private parties was insufficient in light of traditional libel requirements, observing that "the 'actual malice' doctrine is not necessarily applicable in relation to . . . [the nonpublic defamed]." 18 Thus, no court has yet squarely confronted the problem of defamation incidental to statements made about a public official in light of Sullivan; two ${ }^{17}$ have intimated that different standards should be applied; one, ${ }^{18}$ that the standards are identical. No court has articulated any criteria by which to determine the nature of the relationship necessary for the extension of the privilege to the private plaintiff.

A search for the solution to the problem of incidental defamation in the public official situation will probably lead courts to an examination of pre-

1021 App. Div. 2d at 520, 251 N.Y.S.2d at 825 . While the decision could be read to say only that plaintiff had shed his private status by entering the arena of public debate, the court's language seems to call for a broader reading. See id. at 526, 251 N.Y.S.2d at 831; text accompanying note 11 infra. The lone dissenter contended that the case was distinguishable from Sullivan, since the statement was critical of the mayor in his private capacity as a legal practitioner. 21 App. Div. 2d at 528, 251 N.Y.S.2d at 833 .

11 Id. at 526, 251 N.Y.S.2d at 831.

1244 Misc. 2d 1053, 255 N.Y.S.2d 767 (Sup. Ct. 1964).

13 Complaint of Plaintiff, p. 8.

14 Block v. Benton, 44 Misc. 2d 1053, 255 N.Y.S.2d 767 (Sup. Ct. 1964) (dictum). 1586 N.J. Super. 217, 206 A.2d 591 (App. Div. 1965).

18 Id. at $234,206 \mathrm{~A} .2 \mathrm{~d}$ at 600 . Neither the state nor the defendants raised this issue in the briefs.

17 State v. Browne, 86 N.J. Super. 217, 206 A.2d 591 (App. Div. 1965) ; Block v. Benton, 44 Misc. 2d 1053, 255 N.Y.S.2d 767 (Sup. Ct. 1964).

18 Gilberg v. Goffi, 21 App. Div. 2d 517, 251 N.Y.S.2d 823 (1964). 
Sullivan decisions involving incidental defamation in other privileged situations. One such privileged situation is the legal proceeding. Here American courts have uniformly granted an absolute privilege ${ }^{19}$ limited only by the requirement that the utterance to be protected must be relevant to the legal proceeding. As usually formulated, this test classifies as nonprivileged only those statements so irrelevant to the subject matter of the controversy that no reasonable man could doubt their impropriety. ${ }^{20}$ Technical evidentiary requirements of relevance are eschewed; ${ }^{21}$ thus it is often said that courts are to be liberal in permitting a wide range of statement. ${ }^{22}$

19 Prosser $\$ 109$; Restatement $\$ \S 585-89$. Dean Prosser employs "absolute immunity" rather than privilege to indicate that, even if plaintiff proves the defamatory statement to have been made with actual malice, recovery will be denied. $I d$., $\$ 109$, at 796. However, the essential question here is almost identical to that posed by Sullivan, i.e., in either case the judge must decide if the privilege shall be extended to cover incidental defamation.

The policy justification for the two privileges is also similar. The necessity for free political discussion creates the Sullivan privilege; the necessity for free institution, defense and participation in legal proceedings creates the judicial privilege. Compare New York Times Co. v. Sullivan, 376 U.S. 254, 269 (1964), with Jones v. Trice, 210 Tenn. 535, 541, 360 S.W.2d 48, 51 (1962).

The judicial privilege apparently protects incidental defamation in every phase of legal proceedings. E.g., Ginsburg v. Black, 192 F.2d 823 (7th Cir. 1951) (amicus curiae briefs), cert. denied, 343 U.S. 934 (1952); Brown v. Shimabukuro, 118 F.2d 17 (D.C. Cir. 1941) (affidavits in support of summary judgment); Veazy v. Blair, 86 Ga. App. 721, 72 S.E.2d 481 (1952) (testimony of a witness); Anderson v. Hartley, 222 Iowa 921,270 N.W. 460 (1936) (intervenor petition); Nickovich v. Mollart, 51 Nev. 306, 274 Pac. 809 (1929) (hearing on citizenship application); Schneider v. Sachs Quality Stores, Inc., 14 Misc. 2d 582, 179 N.Y.S.2d 409 (Sup. Ct. 1958) (garnishee action); Jones v. Trice, supra (motions for new trial). A few older Tennessee cases distinguished between parties to the suit and strangers, the latter being subject to a conditional privilege only. E.g., Ruohs v. Backer's Next Friend, 53 Tenn. 395 (1871). These holdings, however, have been expressly overruled. Crockett v. McLanahan, 109 Tenn. 517, 72 S.W. 950 (1902).

20 Brown v. Shimabukuro, supra note 19; Young v. Young, 18 F.2d 807 (D.C. Cir. 1927) ; Jones v. Trice, 210 Tenn. 535, 360 S.W.2d 48 (1962). See generally Developments in the Laz-Defamation, 69 HARv. L. REv. 875, 922 (1956). In England, all statements in the course of judicial proceedings are absolutely privileged whether relevant or irrelevant. O'Connor v. Waldron, [1935] A.C. 76 (P.C. 1934) (Can.); Gatley, Libel and Slander 166-73 (London, 5th ed. 1960).

A few cases have required that the statement be relevant to the pleadings. Anonymous v. Trenkman, 48 F.2d 571 (2d Cir. 1931); Union Mut Life Ins. Co. v. Thomas, $83 \mathrm{Fed}$. 803 (9th Cir. 1897). This test would appear to be somewhat narrower than the usual American rule for, presumably, a statement could be relevant to the subject matter of the controversy but not relevant to an issue raised by the pleadings. See Battu v. Smoot, 211 App. Div. 101, 206 N.Y. Supp. 780 (1924). The unusual case in which a statement might be relevant to an extraneous allegation in the pleadings but not to the subject matter of the controversy has not occurred.

One early case insisted that the question of relevancy was for the jury. White v. Carroll, 42 N.Y. 161 (1870). Today, the question is uniformily regarded as one for the court. E.g., Young v. Young, supra; Wels v. Rubin, 280 N.Y. 233, 20 N.E.2d 737 (1939); Jones v. Trice, 210 Tenn. 535, 360 S.W.2d 48 (1962).

21 Ibid.; Crockett v. McLanahan, 109 Tenn. 517, 72 S.W. 950 (1903). Even though the statement is irrelevant as a matter of law or insufficient as a defense, the privilege is not necessarily lost. Irwin v. Newby, 102 Cal. App. 110, 282 Pac. 810 (Ct. App. 1929).

22 Hardtner v. Salloum, 148 Miss. 346, 114 So. 621 (1927); Penick v. Ratcliffe, $149 \mathrm{Va}$. 618, 140 S.E. 664 (1927). Courts appear to take these protestations of liberality seriously: out of 27 reported decisions concerning incidental defamation in judicial proceedings, only 6 (approximately 20\%) found the statements to be irrelevant.

Those cases holding statements irrelevant seem obviously correct on their facts. E.g., Dodge v. Gilman, 122 Minn. 177, 142 N.W. 147 (1913) (allegation that plaintiff 
Five cases involving statements made in divorce proceedings demonstrate the typical situations in which an incidental defamatory accusation was held to be relevant and therefore privileged: friend of wife acted as her procurer ${ }^{23}$ father of wife blackmailed husband ${ }^{24}$ father of wife falsely preferred charges against husband; ${ }^{25}$ neighbor of husband lived in "notorious concubinage" with him; ${ }^{26}$ friend of husband had cohabited with wife. ${ }^{27}$ A Tennessee court has stated the prevalent judicial attitude toward incidental defamation in this area:

The fact that cases of hardship may arise, and persons who have been defamed in the course of judicial proceedings may be left remediless, is no reason why a wholesome legal principle, founded upon reasons of public policy, should be overthrown. A multitude of instances might be cited where the rights of the individual are required to be sacrificed for the public good. ${ }^{28}$

In addition to the cases dealing with incidental defamation in the context of an absolute privilege, future courts attempting to resolve the problem of defamation incidental to statements about a public official may obtain some guidelines from the cases delimiting the scope of qualified privileges generally. ${ }^{29}$ In determining the extent of qualified privileges courts occasionally employ the test of whether the defamation was necessary to an explanation of the privileged communication. ${ }^{30}$ If the incidental defama-

had stolen hay and cut defendant's fence in contest with third party over the ownership of a cow); McLaughlin v. Cowley, 127 Mass. 316 (1879) (allegation that plaintiff had committed murder and adultery in an action to recover for losses sustained by reason of his employment).

23 Veazy v. Blair, 86 Ga. App. 721, 72 S.E.2d 481 (1952).

24 Young v. Young, 18 F.2d 807 (D.C. Cir. 1927).

25 Brown v. Shimabukuro, 118 F.2d 17 (D.C. Cir. 1941).

20 Sunseri v. Shapiro, 138 So. $2 d 661$ (La. Ct. App. 1962).

27 Jones v. Brownlee, 161 Mo. 258, 61 S.W. 795 (1901). See Glasson v. Bowen, 84 Colo. 57, 267 Pac. 1066 (1928) (in petition for change of venue, allegation that sheriff packed jury lists held privileged); Groes v. White, 201 Mo. App. 248, 210 S.W. 920 (1919) (in probate proceeding, allegation that stranger to the suit had stolen defendant's crops held privileged); Nickovich v. Mollart, 51 Nev. 306, 274 Pac. 809 (1929) (during naturalization hearing, testimony that applicant's wife was "willing white slave" held privileged).

28 Crockett v. McLanahan, 109 Tenn. 517, 530-31, 72 S.W. 950, 953 (1903); accord, Jones v. Trice, 210 Tenn. 535, 360 S.W.2d 48 (1962). Federal and most state executive personnel are invested with an absolute privilege based upon a policy-necessity of unhampered functioning of government-similar to that forming the basis of Sullivan. E.g., Barr v. Matteo, 360 U.S. 564 (1959); Sheridan v. Crisona, 14 N.Y.2d 108, 198 N.E.2d 359, 249 N.Y.S.2d 161 (1964). Here, too, courts have recognized that the relevancy of the statement to the official's duties is the pivotal inquiry in determining whether the statement is privileged. Barr v. Matteo, 256 F.2d 890 (D.C. Cir. 1958), aff'd, 360 U.S. 564 (1959); Mellon v. Brewer, 18 F.2d 168 (D.C. Cir.) (dictum), cert. denied, 275 U.S. 530 (1927).

29 Perhaps the most inclusive definition is that the defamation is qualifiedly privileged when "it is fairly made by a person in the discharge of some public or private duty, whether legal or moral, or in the conduct of his own affairs, in matters where his interest is concerned." Toogood v. Spring, 1 C.M. \& R. 181, 193, 149 Eng. Rep. 1044, 1049-50 (Ex. 1834).

30 Leonard v. Wilson, 150 Fla. 503, 8 So. 2d 12 (1942) (dictum); GATLEY, op. cit. supra note 20, at 269. But cf. Nevill v. Fine Arts \& General Ins. Co., [1895] 2 Q.B. 156. 
tion is classified as inseparable from the privileged statement, the privilege is also applicable to the incidental defamation. ${ }^{31}$ Thus, one court has concluded that "the protection of the occasion extends to the statement of all facts necessary to develop the whole truth." 32

Problems of incidental defamation arising within the context of a qualified common interest privilege ${ }^{33}$ may be resolved by means of a relevancy test. ${ }^{34}$ Irrelevancy is usually found only when the statement in no way furthered legitimate common interests. ${ }^{35}$ That the tests of necessity and relevancy are not identical is illustrated by the factual situation presented in Moore v. Manufacturers' Nat'l Bank, ${ }^{36}$ where defendant bank was investigating shortages of a cashier. In a report to its surety, the bank asserted that part of the shortages of the cashier had been traced to collusion with a teller, the plaintiff. Though arguably relevant to an explanation of the disappearance of the funds, the statement was not necessary to any claim the bank might file against the surety.

In applying to the public official situation the two principles of necessity and relevancy, courts will have to balance the social interests involved, as did the Supreme Court in deciding Sullivan. ${ }^{37}$ The Court left little doubt that the balance should be weighted heavily in favor of unrestricted speech when it said that state libel laws must be considered "against the background of a profound national commitment to the principle that debate on public issues should be uninhibited, robust, and wide-open . . . ."38 Moreover, throughout Sullivan the Court emphasized the broadness of its decision, asserting that "the interest of the public here outweighs the

31 Etchison v. Pergerson, $88 \mathrm{Ga}$ 620, 15 S.E. 680 (1892). But see Coombs v. Rose, 8 Black. 155 (Ind. 1846). The Etchison rule is well settled in England. Davies v. Snead, [1870] 5 Q.B. 608; Manby v. Witt, 18 C.B. 544, 139 Eng. Rep. 1482 (C.P. 1856) ; Findley v. Foulds, 19 Vict. L.R. 447 (Austi. 1893). The Etchison rule is apparently followed in Canada. See Knapp v. McLeod, 58 Ont. L.R. 605, [1926] 2 D.L.R. 1083 (1926).

32 Etchison v. Pergerson, supra note 31, at 625, 15 S.E. at 681. Compare Robinett v. Ruby, 13 Md. 95 (1859).

33 The common interest privilege arises when "any one of several persons having a common interest in a particular subject matter correctly or reasonably . . . believe[s] that facts exist which another sharing such common interest is entitled to know." Restatement $\$ 596$. See generally 1 HARPER \& JAMES $\$ 5.26$, at $442-45$; Prosser $\$ 110$, at 809-11.

34 Smith Bros. Co. v. Agee \& Co., 178 Ala. 627, 59 So. 647 (1912) (allegation during creditors' meeting that plaintiff had helped to dispose fraudulently of debtor's assets found relevant and privileged); Brinsfield v. Howeth, $107 \mathrm{Md}$. 278, 68 Ati. 566 (1908) (statement that school commissioner had appointed "fast girls" as school teachers and that one of them, plaintiff, had become pregnant found relevant and privileged).

35 Merchants' Ins. Co. v. Buckner, 98 Fed. 222 (6th Cir. 1899) ; Moore v. Manufacturers' Nat'1 Bank, 123 N.Y. 420, 25 N.E. 1048 (1890).

36 Ibid.

37 New York Times Co. v. Sullivan, 376 U.S. 254, 281 (1964). The debate still smoulders as to whether a case by case balancing of interests is the proper approach to first amendment questions. See Frantz, The First Amendment in the Balance, 71 Yare L.J. 1424 (1962); an answer, Mendelson, On the Meaning of the First Amendment: Absolute in the Balance, 50 CALIF. L. REv. 821 (1962); and a rebuttal, Frantz, Is the First Amendment Law?-A Reply to Professor Mendelson, 51 CaLIF. L. REv. 729 (1963).

38 New York Times Co. v. Sullivan, 376 U.S. 254, 270 (1964). 
interest of appellant or any other individual." 39 "Any other individual" could have been limited to "any other public official," thus confining the extent of the privilege to public officials, had such been the Court's intention. Thus the tenor of Sullivan strongly suggests that the right to criticize the conduct of public officials is generally superior to the interest in reputation of an incidentally defamed individual. Courts adopting the necessity and relevancy tests may therefore be impelled by Sullivan to give them an interpretation favorable to defendants when dealing with speech about a public official.

The cases from which the relevancy and necessity tests are derived suggest that the policies underlying the establishment of a privilege will often require the privilege's extension to incidental defamation. ${ }^{40}$ For example, relevancy, when used as a test to measure the extent of privilege in judicial proceedings, has usually received an interpretation broad enough to cover most incidental defamations. ${ }^{41}$

In deciding Sullivan the Supreme Court indicated a fear that the prospect of libel judgments virtually unlimited in amount would lead to self-censorship by newspapers and other critics. ${ }^{42}$ Recovery by a private individual could have an equally adverse effect. Furthermore, the specificity which may result in an incidental defamation is often necessary and desirable in order to lend credence to accusations; a bland statement, lacking detailed support, is likely to be dismissed by the electorate as sheer propaganda. ${ }^{43}$ The private plaintiff is not, of course, entirely without redress. Even if the Sullivan requirements are applied to incidental defamations, he can recover if able to meet the admittedly stringent test of actual malice. ${ }^{44}$

39 Id. at 272, quoting from Sweeney v. Patterson, 128 F.2d 457, 458 (D.C. Cir.), cert. deried, 317 U.S. 678 (1942). (Emphasis added.)

40 See note 8 supra and cases cited note 19 supra.

41 Cases cited note 22 supra.

The absolute privilege for defamation by government executives has received a similarly broad application. See Gray, Private Wrongs of Public Servants, 47 CaLrF. L. REv. 303 (1959); Handler \& Klein, The Defense of Privilege in Defamation Suits Against Government Executive Officials, 74 HARv. L. Rev. 44 (1960). This interpretation gains added force when viewed in light of the Court's statement in Sullivan that the qualified privilege to criticize public officials was "appropriately analogous" to the executive privilege. 376 U.S. at 282 .

42376 U.S. at 278.

$43 \mathrm{Key}$, Politics, Parties, and Pressure Groups 474-75 (5th ed. 1964); see Associated Press v. Walker, 393 S.W.2d 671, 680 (Tex. Civ. App. 1965), quoting Davis, The Press and the Law in Texas 74 (1956); Brembeck \& Howel, Persuasion: A Means of Social Control 234-39 (1963).

44 It is arguable that the incidentally defamed plaintiff can recover on either of two states of fact: (1) the incidental defamation was made with actual malice toward him; or (2) the direct defamation was made with actual malice toward the public official. In the latter case, the actual malice toward the public official may be regarded as having deprived the entire occasion of its privileged nature.

Juries might be more likely to discern the requisite malice when a private party is unnecessarily made part of the defamation. Mr. Justice Black contends that the actual malice standard is "at best an evanescent protection." He apparently believes that once a case is submitted to the jury, local predilections might cause the jurors to ignore the instructions no matter how carefully phrased. New York Times Co. v. Sullivan, 276 U.S. 254, 293-95 (1964) (concurring opinion). 
It would appear that the two courts intimating that different standards should be applicable to suits of public and private plaintiffs did not explore the question adequately, for an application of the relevancy and necessity tests would have resulted in an extension of the Sullivan privilege to the incidental defamations. In Block $v$. Benton ${ }^{45}$ the defamation of the property owner was both relevant to the charge of improper assessment and necessary to a complete demonstration that some properties had been actually undervalued. ${ }^{46}$ Similarly, to declare that an affidavit was fraudulent would necessarily implicate the affiant, though this connection was not noted by the Browne court. ${ }^{47}$

The individual's interest in the protection of his reputation and in the vindication of injury are the polestars of defamation law.48 Against these interests must be balanced the basic tenet of a democratic society that an informed public free to speak on public questions is necessary for intelligent self-government. ${ }^{49}$ Courts charged with such a balancing task would do well to remember Judge Edgerton's admonition: "Whatever is added to the field of libel is taken from the field of free debate." 50

4544 Misc. 2d 1053, 255 N.Y.S.2d 767 (Sup. Ct. 1964).

46 Block bears a striking factual resemblance to Crockett v. McLanahan, 109 Tenn. 517, 72 S.W. 950 (1903), where, in order to show that an election was void, it was necessary to allege that plaintiff's vote was illegally cast. The statement was held privileged.

47 State v. Browne, 86 N.J. Super. 217, 206 A.2d 591 (App. Div. 1965). Compare Hammett v. Hunter, 189 Okla. 455, 117 P.2d 511 (1941), a child custody case, where an allegation that the mother left the child in the charge of unsavory persons was held necessarily to involve plaintiff who often cared for the infant.

48 MoRris, TORTs 284-86 (1953). The need for safeguarding these dual interests is arguably even greater when an incidental defamation causes a private party to become the subject of public discussion, for the private plaintiff did not choose to enter public life and thus "assume the risks" of public criticism. It has been suggested that retraction or reply statutes offer a solution to the injuries inherent in the expanded privilege accorded by Sullivan. 44 B.U.L. REv. 563, 570-71 (1964). See generally Donnelly, The Right of Reply: An Alternative to an Action for Libel, 34 VA. L. REv. 867 (1948). Such a solution would appear to be equally applicable to the incidental defamation.

$49 \mathrm{~A}$ balancing process is the technique usually employed to reconcile conflicting interests in defamation law. "Immunity is granted or withheld on the principle of the residuum of social convenience deriving from the protection of one interest at the expense of another." 1 HARPER \& JAMES \&5.25, at 435.

50 Sweeney v. Patterson, 128 F.2d 457, 458 (D.C. Cir.), cert. denied, 317 U.S. 678 (1942). 